\title{
Nutritional value and fatty acid profile of two wild edible limpets from the Madeira Archipelago
}

\author{
Igor Fernandes ${ }^{1,2}\left(\right.$ Tomásia Fernandes $^{1,2} \cdot$ Nereida Cordeiro $^{1,2,3}$
}

Received: 19 October 2018 / Revised: 27 December 2018 / Accepted: 3 January 2019

(c) Springer-Verlag GmbH Germany, part of Springer Nature 2019

\begin{abstract}
Patella aspera and Patella candei are two abundant limpet species commercially exploited and often used as a delicacy in the Madeira Archipelago, but there is a lack of scientific knowledge about these species. This study investigated the nutritional value and fatty acids of this species across the coast of Madeira Archipelago. The lipid content (7.71-12.60\% dw), proteins $(48.22-64.09 \% \mathrm{dw})$, ashes $(11.12-23.12 \% \mathrm{dw})$ and carbohydrates $(4.5-10.9 \% \mathrm{dw})$ were determined in P. aspera and $P$. cande $i$ at different collection sites. In the fatty acid composition, a total of 23 fatty acids (FAs) were identified. P. aspera showed the highest amount of monounsaturated FAs (MUFAs, 35.02\%) and eicosapentaenoic acid (EPA, 12.59\%), and $P$. candei presented the highest level of oleic acid (OA, 28.25\%), polyunsaturated FAs (PUFAs, 27.26\%) and arachidonic acid (AA, $11.38 \%$ ). The $\Sigma \omega 3 / \Sigma \omega 6$ dietary ratio presented levels $>0.25$ suggesting that these marine molluscs are a good source of $\omega 3$ for dietary intake. Within each specie significant differences $(p<0.05)$ across sites were observed. High amounts of essential nutrients were shown in Patella species collected at Selvagens site while poorest levels were shown in Patella collected at Lido. The evaluation of the nutritional traits of $P$. candei and P. aspera shows that these limpets are good sources of essential fatty acids for human health and that the distribution of limpets is a key factor when determining its dietary value.
\end{abstract}

Keywords Patella candei $\cdot$ Patella aspera $\cdot$ Lipid content $\cdot$ Fatty acid $\cdot$ AA $\cdot$ EPA

\section{Introduction}

The global consumption of seafood has been increasing steadily in the last few years, presenting an average $9.01 \mathrm{~kg}$ per capita in 1960 to $18.98 \mathrm{~kg}$ per capita in 2013 [1]. In Madeira Archipelago (Portugal), limpets are typically found on the rocky shores and form part of the staple diet of the local population. In this region, Patella aspera and Patella cande $i$ are two abundant limpet species commercially exploited and often used as a delicacy in the regional gastronomy [2, 3]. However, despite their great consumption, a lack of scientific work is found regarding these species dietary value and nutritional status.

Igor Fernandes

igor.fernandes@oom.arditi.pt

1 Oceanic Observatory of Madeira, Agência Regional para o Desenvolvimento da Investigação Tecnologia e Inovação, Funchal, Portugal

2 Faculty of Sciences and Engineering, University of Madeira, Funchal, Portugal

3 CIIMAR, University of Porto, Matosinhos, Portugal
The marine resources represent one of the most nutritious foods and are acknowledged as excellent sources of essential nutrients-such as high-quality proteins (amino acids), minerals, vitamins and lipids, that positively affect the human health [4-7]. For instance, the essential fatty acids (LA and ALA) and the long chain polyunsaturated fatty acids (LCPUFA) are essential components of the biological membranes and precursors of a variety of signalling molecules (e.g. leukotrienes, eicosanoids, thromboxanes) responsible for multiple physiological and pathological responses [6, 8-11]. Nevertheless, humans do not have the ability to synthesize them and thus their intake through diet is crucial. Moreover, research regarding the relations between diet and disease have linked the intake of these fatty acids with the prevention of cardiovascular diseases and cancer, reduction of coronary heart disease, decrease of mild hypertension and alleviation of the symptoms of rheumatoid arthritis [8-13].

Although the scientific community has already pointed dietary benefits of consuming other limpet species, such as $P$. depressa, $P$. ulyssiponensis, $P$. vulgate, $P$. rustica and $P$. peroni, scarce information is available about $P$. aspera and $P$. cande $i$ as important natural sources of essential nutrients 
to human health $[14,15]$. Also, it is known that the dietary value of seafood is affected by a wide range of factors, such as water temperature, maturity, season, genetics and diet [13]. In Madeira Archipelago the characteristics of seafood is strongly conditioned by geological and environmental conditions [16], that influences the food availability, which, in turn, affects the nutritional value of marine invertebrates, including the limpets species [17]. Therefore, the aims of the present study were to evaluate the dietary value of $P$. cande $i$ and $P$. aspera across the coast of Madeira Archipelago, as potential sources of MUFAs and PUFAs.

\section{Materials and methods}

\section{Chemicals}

All chemicals were of analytical grade. Heptane, methanol, anhydrous sodium sulphate was supplied by
Sigma-Aldrich (Missouri, USA) and ethyl acetate were acquired from Merck (Darmstadt, Germany). Chloroform and sodium chloride were bought from VWR (Carnaxide, Portugal).

\section{Samples collection}

This study was carried out in Madeira, a volcanic island $\left(32^{\circ} 38^{\prime} \mathrm{N}, 16^{\circ} 54^{\prime} \mathrm{W}\right)$ located southwest of continental Europe in the subtropical North Atlantic. Two species of Patella with commercial size $(\geq 4 \mathrm{~cm})$ were collected at a depth of 1-4 $\mathrm{m}$ from seven different sites of coastal Madeira Archipelago (Fig. 1), namely Selvagens, Garajau, Ponta de São Lourenço, Lido, Desertas, Rocha do Navio and Porto Moniz. In the total, 20 individuals per site and specie were caught and the species of Patella aspera (Röding 1798) and Patella candei (d'Orbigny, 1840) were identified according to Weber and Hawkins [3] and Weber and Hawkins [2], respectively. All species were washed and the edible portion was stored

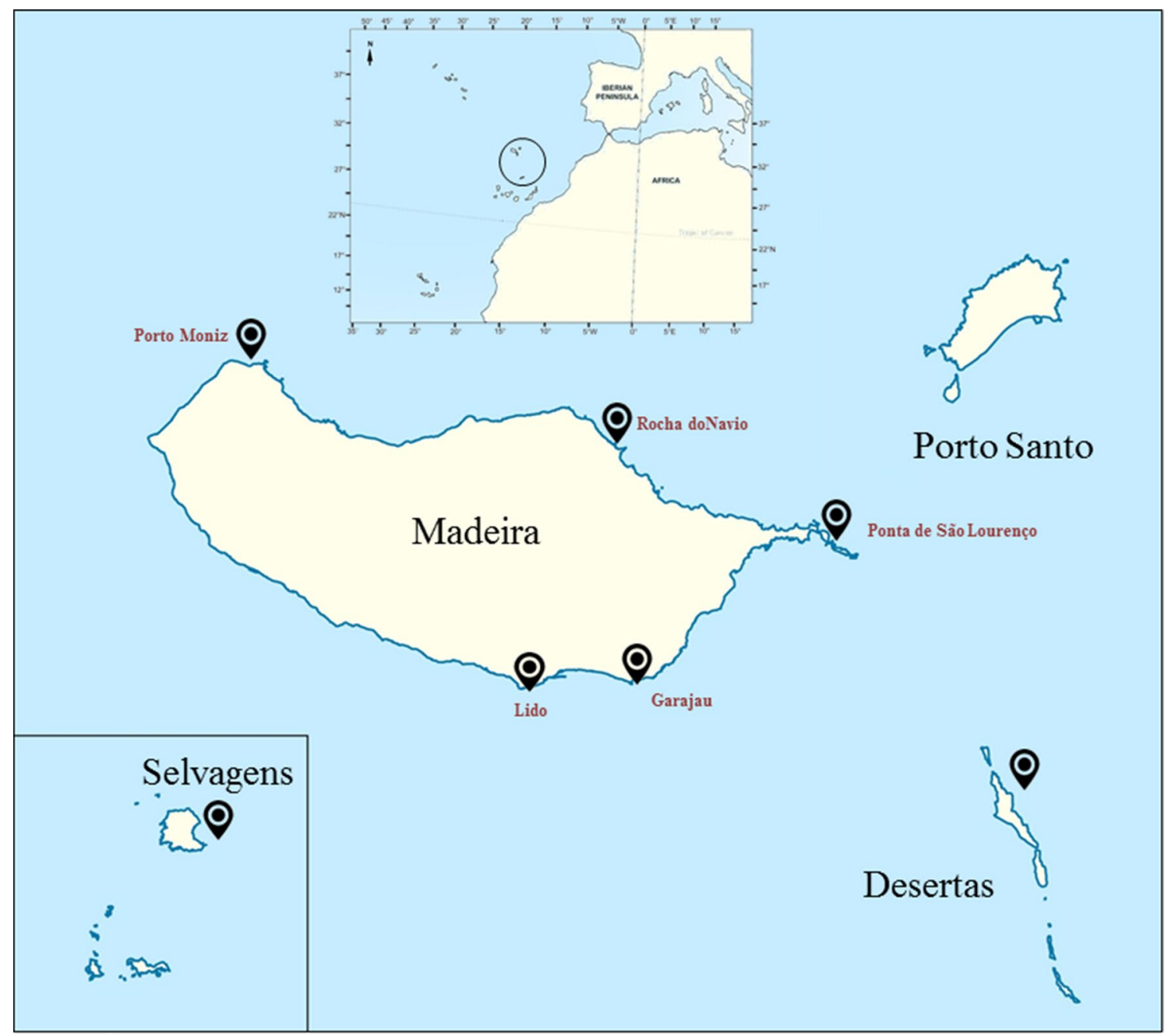

Fig. 1 Map with the location of Madeira Archipelago and the sampling locations reported in the text 
in a freezer at $-20^{\circ} \mathrm{C}$, for a period no longer than 3 months, after homogenization and pooling according to collection site and specie. All pooled samples were then freeze-dried at $-60{ }^{\circ} \mathrm{C}$ and $0.1 \mathrm{mbar}$ in a Savant freeze-dryer. Samples were considered dried when the residual water content was less than $0.4 \%$ (w/w), using a Gibertini Eurotherm electronic moisture balance (Gibertini Elettronica, Novate Milanese MI, Italy).

\section{Proximate composition}

The water content of Patella species was determined in fresh edible portion, with samples to be oven dried at $105{ }^{\circ} \mathrm{C}$,
The FAMEs were identified through comparison of retention times and mass spectra obtained with two standard samples: "bacterial acid methyl esters CP mix" and "Supelco 37 component FAME mix" from Supelco (Missouri, USA). To quantify the FA of the limpet sample, heneicosanoic acid from Sigma-Aldrich (Missouri, USA) was used as an internal standard. The results were expressed in $\mathrm{mg} \mathrm{g}^{-1} \mathrm{dry}$ weight and in percentage of total FA, with the quantification made according to the response factor determined for each FA present in the standards, in comparison with the heneicosanoic acid (internal standard).

The hypocholesterolaemic/hypercholesterolaemic fatty acids ratio $(\mathrm{H} / \mathrm{H})$ was determined according to Fernandes, Vasconcelos [23]:

$\frac{18: 1 \omega 9+18: 2 \omega 6+20: 4 \omega 6+18: 3 \omega 3+20: 5 \omega 3+22: 5 \omega 3+22: 6 \omega 3}{14: 0+16: 0}$

until a constant weight. The ashes content was determined in freeze-dried samples through a muffle furnace, as described by Kalogeropoulos, Chiou [18]. The protein content was determined through an elemental analyser Truspec 630-200200 , by multiplying the nitrogen content per 6.25 . The lipid content was determined according to modified Bligh and Dyer [19] as described in Fernandes, Fernandes [20]. The amount of carbohydrates was estimated from the difference between the ashes, protein and lipid content. The energetic value was determined according to the following equation:

\section{Statistical analysis}

Data are reported as mean of five replicates \pm SD and differences between sites were assessed by one-way analysis of variance (ANOVA), followed by a B-Tukey post hoc analysis, $p$ values of $<0.05$ were considered statistically significant. Principal component analysis (PCA) was applied to summarize the information in a reduced number of principal components. Varimax rotation was selected to represent the planar projection of the loadings (variables) for the two

Energetic value $\left(\frac{\mathrm{kcal}}{100 \mathrm{~g}}\right)=4 \times[(\%)$ carbohydrates $+(\%)$ protein $]+9 \times[(\%)$ lipids $]$

\section{Fatty acid analysis}

Total lipid extracts were analysed for their fatty acid composition as fatty acid methyl esters (FAMEs) as previously described by Lepage and Roy [21], modified by Cohen, Vonshak [22]. Briefly, the fatty acids were converted to FAMEs by adding a mixture of ethyl acetate-methanol (1:19 v/v) to total lipid aliquots which was then kept at $80^{\circ} \mathrm{C}$ for $1 \mathrm{~h}$. FAMEs were analysed by gas chromatography (Agilent HP 6890-California, USA) equipped with a mass selective detector (Agilent 5973 - California, USA) and a fused silica capillary column Supelcowax ${ }^{\mathrm{TM}} 10(30 \mathrm{~m} \times 0.25 \mathrm{~mm}$ inner diameter, $0.25 \mu \mathrm{m}$ film thickness) from Supelco (Missouri, USA). The chromatographic conditions were: initial temperature, $40{ }^{\circ} \mathrm{C}$ for $5 \mathrm{~min}$; temperature gradient, $2{ }^{\circ} \mathrm{C} \mathrm{min}^{-1}$; final temperature, $250{ }^{\circ} \mathrm{C}$ for $5 \mathrm{~min}$; injector temperature, $260{ }^{\circ} \mathrm{C}$; transfer-line temperature, $260{ }^{\circ} \mathrm{C}$; split ratio, $1: 100$. Helium was used as the carrier gas with a flow of $1.0 \mathrm{~mL}$ $\min ^{-1}$. principal components. All statistical analyses were performed using SPSS. v 23 for Windows.

\section{Results and discussion}

\section{Proximate composition}

It is known that the proximate composition determines food palatability and dietary value. Despite the high consumption of Patella candei and Patella aspera, scarce or non-existent information is found with respect to their biochemical composition. The proximate compositions for $P$. cande $i$ and $P$. aspera are shown in Tables 1 and 2, respectively. The traits analysed for the two limpets showed significant differences $(p<0.05)$ across sites. Moisture contents varied between $41.06 \%$ and $53.59 \%$, with $P$. candei displaying the highest amount quantified. The species under study, presented much lower amounts than other molluscs of Pacific Sea, such as, 
Table 1 Proximate composition and energetic value (kcal/100 g, wet basis) of edible mollusc P. candei in different collection sites

\begin{tabular}{|c|c|c|c|c|c|c|}
\hline Site & Moisture $^{1}$ & Total lipid² & Crude protein ${ }^{2}$ & Total carbohydrate $^{2}$ & Total ashes ${ }^{2}$ & Energetic value $^{3}$ \\
\hline Selvagens & $44.05 \pm 2.38^{\mathrm{a}}$ & $8.26 \pm 0.35^{\mathrm{a}}$ & $57.14 \pm 0.98^{\mathrm{a}}$ & $15.22 \pm 1.28^{\mathrm{a}}$ & $19.38 \pm 0.05^{\mathrm{a}}$ & $203.55 \pm 1.11^{\mathrm{a}}$ \\
\hline Garajau & $41.30 \pm 1.73^{b}$ & $11.63 \pm 0.54^{\mathrm{b}}$ & $57.28 \pm 2.00^{\mathrm{a}}$ & $16.06 \pm 2.60^{\mathrm{a}}$ & $15.02 \pm 0.07^{\mathrm{b}}$ & $233.68 \pm 1.41^{\mathrm{b}}$ \\
\hline Ponta de São Lourenço & $53.59 \pm 0.16^{\mathrm{c}}$ & $7.98 \pm 0.34^{\mathrm{a}}$ & $48.22 \pm 1.32^{\mathrm{b}}$ & $23.07 \pm 1.03^{\mathrm{b}}$ & $20.73 \pm 0.05^{\mathrm{c}}$ & $165.67 \pm 0.88^{c}$ \\
\hline Lido & $50.38 \pm 1.29^{\mathrm{c}, \mathrm{d}}$ & $9.84 \pm 0.10^{\mathrm{c}}$ & $59.74 \pm 1.76^{\mathrm{a}}$ & $9.66 \pm 1.51^{\mathrm{a}, \mathrm{c}}$ & $20.76 \pm 0.35^{\mathrm{c}}$ & $181.69 \pm 0.93^{\mathrm{d}}$ \\
\hline Desertas & $47.94 \pm 0.66^{\mathrm{a}, \mathrm{d}}$ & $9.17 \pm 0.19^{\mathrm{a}, \mathrm{c}}$ & $59.88 \pm 2.44^{\mathrm{a}}$ & $7.84 \pm 2.66^{c}$ & $23.12 \pm 0.02^{\mathrm{d}}$ & $183.95 \pm 0.45^{\mathrm{d}}$ \\
\hline Rocha do Navio & $43.94 \pm 0.25^{\mathrm{a}, \mathrm{b}}$ & $9.61 \pm 0.46^{\mathrm{c}}$ & $61.98 \pm 0.62^{\mathrm{a}}$ & $11.66 \pm 1.00^{\mathrm{a}}$ & $16.76 \pm 0.08^{\mathrm{e}}$ & $213.59 \pm 1.47^{\mathrm{e}}$ \\
\hline
\end{tabular}

Different letters in the same column have significant differences $(p<0.05)$

Data presented as mean \pm standard deviation $(n=5)$

${ }^{1}$ Values expressed in $\%(\mathrm{~g} / 100 \mathrm{~g}$ of wet basis)

${ }^{2}$ Values expressed in $\%$ (g/100 $\mathrm{g}$ of dry weight basis)

${ }^{3}$ Values expressed in $\mathrm{kcal} / 100 \mathrm{~g}$ of wet basis

Table 2 Proximate composition and energetic value (kcal/100 g, wet basis) of edible mollusc P. aspera in different collection sites

\begin{tabular}{|c|c|c|c|c|c|c|}
\hline Site & Moisture $^{1}$ & Total lipid ${ }^{2}$ & Crude protein ${ }^{2}$ & Total carbohydrate ${ }^{2}$ & Total ashes ${ }^{2}$ & Energetic value $^{3}$ \\
\hline Selvagens & $49.97 \pm 1.80^{\mathrm{a}}$ & $7.75 \pm 0.27^{\mathrm{a}}$ & $64.09 \pm 0.36^{\mathrm{a}}$ & $15.17 \pm 0.65^{\mathrm{a}}$ & $12.99 \pm 0.01^{\mathrm{a}}$ & $193.53 \pm 0.64^{\mathrm{a}}$ \\
\hline Garajau & $45.90 \pm 2.94^{\mathrm{a}, \mathrm{b}}$ & $11.05 \pm 0.15^{\mathrm{b}}$ & $60.85 \pm 1.94^{\mathrm{a}}$ & $16.98 \pm 2.16^{\mathrm{a}}$ & $11.12 \pm 0.07^{\mathrm{b}}$ & $222.21 \pm 0.25^{\mathrm{b}}$ \\
\hline Ponta de São Lourenço & $41.06 \pm 1.95^{\mathrm{b}}$ & $12.60 \pm 0.54^{\mathrm{c}}$ & $58.42 \pm 0.11^{\mathrm{a}}$ & $15.83 \pm 0.58^{\mathrm{a}}$ & $13.15 \pm 0.08^{\mathrm{a}}$ & $241.86 \pm 1.78^{\mathrm{c}}$ \\
\hline Lido & $47.22 \pm 0.47^{\mathrm{a}, \mathrm{b}}$ & $11.45 \pm 0.56^{\mathrm{b}, \mathrm{c}}$ & $57.20 \pm 3.81^{\mathrm{a}}$ & $13.04 \pm 2.95^{\mathrm{a}}$ & $18.31 \pm 0.31^{\mathrm{c}}$ & $202.67 \pm 0.82^{\mathrm{d}}$ \\
\hline Desertas & $45.33 \pm 0.87^{\mathrm{a}, \mathrm{b}}$ & $7.71 \pm 0.38^{\mathrm{a}}$ & $58.98 \pm 0.28^{\mathrm{a}}$ & $16.38 \pm 0.50^{\mathrm{a}}$ & $16.92 \pm 0.40^{\mathrm{d}}$ & $202.77 \pm 0.17^{\mathrm{d}}$ \\
\hline Rocha do Navio & $44.40 \pm 1.69^{\mathrm{a}, \mathrm{b}}$ & $10.30 \pm 0.14^{\mathrm{b}}$ & $60.64 \pm 2.32^{\mathrm{a}}$ & $16.57 \pm 2.84^{\mathrm{a}}$ & $12.49 \pm 0.66^{\mathrm{a}, \mathrm{e}}$ & $223.27 \pm 1.85^{\mathrm{b}}$ \\
\hline Porto Moniz & $47.18 \pm 2.79^{\mathrm{a}, \mathrm{b}}$ & $10.21 \pm 0.62^{\mathrm{b}}$ & $59.73 \pm 1.78^{\mathrm{a}}$ & $18.38 \pm 2.49^{\mathrm{a}}$ & $11.69 \pm 0.09^{b, e}$ & $213.56 \pm 1.43^{\mathrm{e}}$ \\
\hline
\end{tabular}

Data presented as mean \pm standard deviation $(n=5)$

Different letters in the same column have significant differences $(p<0.05)$

${ }^{1}$ Values expressed in \% (g/100 g of wet basis)

${ }^{2}$ Values expressed in \% (g/100 g of dry weight basis)

${ }^{3}$ Values expressed in $\mathrm{kcal} / 100 \mathrm{~g}$ of wet basis

clams (79.4-91.8\%), oysters (85.4\% and $88.3 \%$ ) and scallops (77.8-78.8\%) [24].

Lipid contents of $P$. aspera and $P$. candei ranged from 7.71 to $12.60 \%$ (dry weight basis) with $P$. aspera comprising slight higher amounts of this macromolecular pool than P. candei. According to Ackman [25] these species can be considered as a high fat resource for human diet, since the values found for the lipid content are higher than $8 \%$ in dry weight. However, some exceptions can be found, for instance $P$. aspera collected at Selvagens and Desertas, and $P$. candei collected at Selvagens and Ponta de São Lourenço, where the fat content is lower and/or equal to $8 \%$. In the literature similar lipid levels have been reported for other molluscs, namely two species of oysters in offshore aquaculture (Crassostrea gigas, Ostrea edulis; 6.9-14.4\%) [26] and other species of oyster captured in Pacific Sea (Crassostrea virginica; 7.74\% and 9.06\%) [24]. Moreover, Karakoltsidis, Zotos [27] and Miletic, Miric [29] reported contents of lipids in mussel bivalve (Mytilus galloprovincialis) from Mediterranean between 5.56 and $15.38 \%$ and in two marine shellfish (Venus verrucosa, Mytilus galloprovincialis) from the Adriatic Sea levels between 5.43 and 9.61\%. Other studies in Pacific sea revealed lowest lipids levels in scallops $(0.78-0.95 \%)$ and clams (1.65-7.60\%) [24] and, highest lipid contents in sea urchin (Paracentrotus lividus) from Sardinia (15.52-19.26\%).

The levels of crude protein ( $>22 \%$ wet basis) observed for the two limpet species studied were higher than to general seafood (e.g. fish between 15-20\% wet basis) [28] Therefore, these limpets can be considered as a rich natural source of protein for human consumption. The highest amount of protein was verified for $P$. aspera collected in Selvagens $(64.09 \% \mathrm{dw})$, whereas the lowest was found in P. candei collected in Ponta de São Lourenço $(48.22 \% \mathrm{dw})$. Nevertheless, these limpets showed similar amounts when compared to other marine molluscs, namely clams, oysters and mussels [24, 27, 30]. Likewise, lower levels of crude protein were found in other aquaculture oysters and bivalves from Adriatic Sea [26, 29], while highest levels were found in scallops captured in Pacific Sea [24]. 
There are significant differences $(p<0.05)$ in the amount of carbohydrate among the samples collected from different locations. In general, the contents of this nutritional trait in samples were higher (4.1-10.7\% wet basis) than to common nutritional composition presented in seafood (e.g. $<2 \%$ wet basis; general fish) [28]. These levels of carbohydrate might be due to the storage of glucose as glycogen, since it is known that some molluscs contain up to $5 \%$ of this storage carbohydrate [28]. P. candei in Ponta de São Lourenço (23.07\%) comprised larger levels of this component than the P. candei collected in Desertas (7.84\%). The Mediterranean mussel (Mytilus galloprovincialis; 15.38-27.78\%) [27] and European oyster (Ostrea edulis; 6.6-23.2\%) [26] presented similar amounts of carbohydrate that those found in the present study. Still, the Linehan, O'Connor [30] studied the seasonal variation of oysters (Crassostrea gigas) in Pacific Sea and obtained higher amounts of carbohydrate between February and June (31.6-38.9\%).

Minerals are essential for the correct functioning of the human body, with seafood being considered a good source of these components ( $<2 \%$ wet basis, edible portion) [ 28 , 31]. Among species higher values of ashes were observed for $P$. candei, namely those collected in Desertas (23.12\% $\mathrm{dw}$ ), in contrast to P. aspera which presented the lowest amount determined $(11.12 \% \mathrm{dw})$ at Garajau. All samples showed higher levels of ash, when compared to other marine molluscs, such as oysters (5.56\% and 7.60\%) and scallops (6.70-8.06\%) of Pacific Sea [24], sea shellfish to the Adriatic Sea (8.14\% and $12.09 \%$ ) [29], mussel bivalves captured in Mediterranean (5.38-11.11\%) [27] and Pacific oysters captured in different months (4.0-12.1\%). Although, Sidwell, Bonnet [24] reported similar ash content in three different species of clams that found in Pacific Sea (Marcenaria mercenaria, 24.02\%; Mya arenaria, 7.13\%; Spisula solidissima $11.12 \%)$. In this study, the limpets investigated revealing the largest content of minerals (6.0-12.0\% dry weight basis), may be considered as excellent sources of minerals for human consumption.

The energetic values found in limpets are directly related to the lipids, crude protein and carbohydrates contents of samples. Only P. candei in Ponta de São Lourenço presented lower levels of energetic values, $<170 \mathrm{kcal} / 100 \mathrm{~g}$ wet basis, which may be recommended to the energy-restricted diets. The other samples that exhibited higher levels of this trait can be suitable for energy-rich diets.

\section{Fatty acid profile}

The FA compositions of $P$. cande $i$ and $P$. aspera at different rocky shores of Madeira Archipelago are found in Tables 3 and 4 , respectively. A total of 23 FAs were identified. The most important saturated fatty acids (SFA) were 14:0, 16:0, 18:0, the monounsaturated fatty acids (MUFAs) 16:1 1 , $18: 1 \omega 9,20: 1 \omega 9$, and the polyunsaturated fatty acids

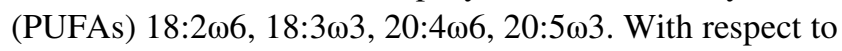
the total fatty acids (TFA) quantified, the highest contents were found in P. aspera ( $36.38 \mathrm{mg} / \mathrm{g}$ dry weight basis) and lowest contents were found in $P$. candei $(17.17 \mathrm{mg} / \mathrm{g}$ dry weight basis).

\section{Saturated fatty acids}

The SFA levels found in the molluscs of all sites examined varied between $39.79 \%$ (P. candei, Selvagens) and $60.03 \%$ (P. candei, Lido) of TFA (Tables 2, 3). The major SFA was palmitic acid (PA, 16:0), with the highest concentration observed in P. aspera (Lido, 41.36\%) and the lowest in $P$. candei (Selvagens, 26.93\%). The lower levels of PA observed in $P$. candei were similar to those previously obtained by Brazão, Morais [14] for other limpets collected in the Portuguese coast, namely P. depressa (16.30-24.49\%) and P. ulyssiponensis (19.35-25.72\%). Higher levels of PA were found in other marine gastropods, such as the Ostrea edulis (flat oyster, 10.35-32.91\%), the Mytilus galloprovincialis (black mussel, 9.10-33.76\%), the Modiolus barbatus (bearded horse mussel, 4.89-36.57\%) and the Arca noae (Noah's ark shell, 4.67-32.05\%) whose maximum levels are within the average values of PA found in both $P$. cande $i$ and $P$. aspera [17].

The sum of the major SFAs (stearic acid-SA, 18:0; myristic acid-MA, 14:0; PA) accounted $37.27-55.75 \%$ of the TFA detected. The lowest value observed $(37.27 \%$ in $P$. candei, Selvagens) for this set of fatty acids constitutes an advantage for dietary intake, since high levels of these fatty acids are related to the promotion of hypercholesterolaemia, formation of thrombus and atheromatous deposits [23]. Moreover, similar levels of MA and SA have been reported for different species of oyster, mussel, limpets, sea snail and nudibranchs [14, 15, 17, 32-36].

Having in account the energetic value previously discussed, it is possible to note that the main contributor for this trait in limpets was mostly protein, in contrast to, lipids were SFAs are included. This constitutes a positive factor since the international dietary guidelines have recommended that SFAs should contribute no more than $10 \%$ of the dietary energy, in order to reduce the prevalence of coronary hearth diseases [37].

\section{Monounsaturated fatty acids}

The substitution of SFAs for MUFAs in manufactured foods for human consumption has been shown to have beneficial effect in health [37]. The MUFAs content in Patella species analysed were about one-third of the 
Table 3 Fatty acid composition of the edible mollusc P. candei at several collection sites, expressed as \% of the total FA detected

\begin{tabular}{|c|c|c|c|c|c|c|}
\hline Fatty acid ( $\%$ of TFA) & Selvagens & Garajau & Ponta de São lourenço & Lido & Desertas & Rocha do Navio \\
\hline $13: 0^{1}$ & $1.22 \pm 0.03^{\mathrm{a}}$ & $3.35 \pm 0.04^{\mathrm{b}}$ & $2.11 \pm 0.05^{\mathrm{c}}$ & $2.37 \pm 0.06^{\mathrm{c}}$ & $2.85 \pm 0.22^{\mathrm{d}}$ & $2.72 \pm 0.10^{\mathrm{d}}$ \\
\hline 14:0 & $2.56 \pm 0.10^{\mathrm{a}}$ & $7.41 \pm 0.13^{\mathrm{b}}$ & $2.99 \pm 0.18^{\mathrm{a}}$ & $7.92 \pm 0.11^{\mathrm{b}}$ & $7.96 \pm 0.34^{\mathrm{b}}$ & $5.15 \pm 0.22^{\mathrm{c}}$ \\
\hline $15: 0$ & $0.58 \pm 0.03^{\mathrm{a}}$ & $1.25 \pm 0.01^{\mathrm{b}}$ & $0.90 \pm 0.00^{c}$ & $1.08 \pm 0.02^{\mathrm{d}}$ & $1.52 \pm 0.07^{\mathrm{e}}$ & $1.32 \pm 0.05^{\mathrm{b}}$ \\
\hline $16: 0$ & $26.93 \pm 0.08^{\mathrm{a}}$ & $32.10 \pm 0.36^{\mathrm{b}}$ & $37.24 \pm 0.76^{\mathrm{c}}$ & $36.76 \pm 0.30^{c}$ & $37.19 \pm 0.61^{\mathrm{c}}$ & $35.25 \pm 0.94^{\mathrm{b}, \mathrm{c}}$ \\
\hline $17: 0$ & $0.27 \pm 0.00^{\mathrm{a}}$ & $0.74 \pm 0.00^{\mathrm{b}}$ & $0.61 \pm 0.01^{\mathrm{c}}$ & $0.75 \pm 0.02^{\mathrm{b}}$ & $0.84 \pm 0.00^{\mathrm{d}}$ & $1.20 \pm 0.01^{\mathrm{e}}$ \\
\hline 18:0 & $7.78 \pm 0.15^{\mathrm{a}}$ & $10.53 \pm 0.14^{b, c}$ & $10.55 \pm 0.01^{\mathrm{b}, \mathrm{c}}$ & $11.07 \pm 0.19^{c}$ & $8.58 \pm 0.13^{\mathrm{d}}$ & $10.18 \pm 0.05^{\mathrm{b}}$ \\
\hline $20: 0$ & $0.34 \pm 0.01^{\mathrm{a}}$ & $0.23 \pm 0.01^{\mathrm{b}}$ & $0.23 \pm 0.01^{\mathrm{b}}$ & $0.07 \pm 0.00^{\mathrm{c}}$ & $0.18 \pm 0.01^{\mathrm{d}}$ & $0.41 \pm 0.01^{\mathrm{e}}$ \\
\hline $22: 0$ & $0.13 \pm 0.02^{\mathrm{a}}$ & $0.06 \pm 0.00^{\mathrm{b}}$ & nd & nd & nd & $0.02 \pm 0.00^{c}$ \\
\hline$\Sigma$ SFA & $39.79 \pm 0.12^{\mathrm{a}}$ & $55.68 \pm 0.39^{\mathrm{b}, \mathrm{c}}$ & $54.63 \pm 0.99^{\mathrm{b}}$ & $60.03 \pm 0.27^{\mathrm{c}}$ & $59.11 \pm 1.08^{\mathrm{b}, \mathrm{c}}$ & $56.27 \pm 1.26^{\mathrm{b}, \mathrm{c}}$ \\
\hline $16: 1 \omega 7$ & $1.22 \pm 0.07^{\mathrm{a}}$ & $3.73 \pm 0.02^{\mathrm{b}}$ & $0.47 \pm 0.01^{\mathrm{c}}$ & $3.58 \pm 0.01^{\mathrm{b}, \mathrm{d}}$ & $1.47 \pm 0.01^{\mathrm{e}}$ & $3.38 \pm 0.07^{\mathrm{d}}$ \\
\hline $18: 1 \omega 9$ & $28.25 \pm 0.18^{\mathrm{a}}$ & $19.33 \pm 0.09^{b}$ & $20.01 \pm 0.29^{b, c}$ & $19.84 \pm 0.13^{\mathrm{b}, \mathrm{c}}$ & $21.73 \pm 0.22^{\mathrm{d}}$ & $20.73 \pm 0.22^{\mathrm{c}, \mathrm{d}}$ \\
\hline 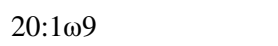 & $3.47 \pm 0.04^{\mathrm{a}}$ & $5.27 \pm 0.07^{\mathrm{b}, \mathrm{c}}$ & $4.97 \pm 0.35^{\mathrm{a}, \mathrm{b}}$ & $6.32 \pm 0.09^{\mathrm{b}, \mathrm{c}}$ & $6.70 \pm 0.32^{\mathrm{c}}$ & $6.40 \pm 0.44^{b, c}$ \\
\hline$\Sigma$ MUFA & $32.95 \pm 0.10^{\mathrm{a}}$ & $28.33 \pm 0.14^{\mathrm{b}}$ & $25.45 \pm 0.65^{\mathrm{c}}$ & $29.74 \pm 0.22^{\mathrm{b}}$ & $29.90 \pm 0.53^{\mathrm{b}}$ & $30.52 \pm 0.59^{\mathrm{a}, \mathrm{b}}$ \\
\hline $18: 2 \omega 6$ & $4.92 \pm 0.01^{\mathrm{a}}$ & $0.73 \pm 0.00^{\mathrm{b}}$ & $2.19 \pm 0.10^{\mathrm{c}}$ & $0.05 \pm 0.00^{\mathrm{d}}$ & $0.59 \pm 0.03^{\mathrm{b}, \mathrm{e}}$ & $0.42 \pm 0.02^{\mathrm{e}}$ \\
\hline $18: 2 \omega 3$ & nd & $0.33 \pm 0.01^{\mathrm{a}}$ & nd & $0.28 \pm 0.02^{\mathrm{b}}$ & nd & $0.04 \pm 0.00^{\mathrm{c}}$ \\
\hline $18: 3 \omega 3$ & $1.79 \pm 0.04^{\mathrm{a}}$ & $0.46 \pm 0.00^{\mathrm{b}}$ & $1.90 \pm 0.09^{\mathrm{a}}$ & nd & $0.33 \pm 0.02^{\mathrm{b}}$ & $0.32 \pm 0.01^{\mathrm{b}}$ \\
\hline $18: 4 \omega 3$ & $0.15 \pm 0.01^{\mathrm{a}}$ & $0.04 \pm 0.00^{\mathrm{b}}$ & nd & nd & nd & $0.01 \pm 0.00^{\mathrm{c}}$ \\
\hline $20: 2 \omega 9$ & $3.00 \pm 0.01^{\mathrm{a}}$ & $1.20 \pm 0.03^{\mathrm{b}}$ & $2.23 \pm 0.08^{c}$ & $0.53 \pm 0.03^{\mathrm{d}}$ & $1.55 \pm 0.09^{\mathrm{e}}$ & $1.19 \pm 0.09^{\mathrm{b}}$ \\
\hline $20: 3 \omega 6$ & $0.14 \pm 0.02^{\mathrm{a}}$ & $0.10 \pm 0.01^{\mathrm{a}}$ & nd & nd & nd & $0.04 \pm 0.00^{\mathrm{b}}$ \\
\hline $20: 4 \omega 6-\mathrm{AA}$ & $11.38 \pm 0.07^{\mathrm{a}}$ & $3.58 \pm 0.06^{\mathrm{b}}$ & $8.42 \pm 0.02^{\mathrm{c}}$ & $2.61 \pm 0.02^{\mathrm{d}}$ & $4.43 \pm 0.22^{\mathrm{e}}$ & $4.37 \pm 0.22^{\mathrm{e}}$ \\
\hline $20: 4 \omega 3$ & $0.12 \pm 0.02^{\mathrm{a}}$ & $0.08 \pm 0.01^{\mathrm{a}}$ & nd & nd & nd & $0.02 \pm 0.00^{\mathrm{b}}$ \\
\hline $20: 5 \omega 3-\mathrm{EPA}$ & $5.71 \pm 0.05^{\mathrm{a}}$ & $9.13 \pm 0.10^{\mathrm{b}}$ & $5.18 \pm 0.05^{\mathrm{a}}$ & $6.66 \pm 0.03^{c}$ & $4.08 \pm 0.18^{\mathrm{d}}$ & $6.62 \pm 0.32^{\mathrm{c}}$ \\
\hline $22: 4 \omega 6$ & $0.02 \pm 0.00^{\mathrm{a}}$ & $0.02 \pm 0.00^{\mathrm{a}}$ & nd & nd & nd & $0.05 \pm 0.00^{\mathrm{b}}$ \\
\hline $22: 5 \omega 3$ & $0.03 \pm 0.00^{\mathrm{a}}$ & $0.30 \pm 0.02^{\mathrm{b}}$ & nd & $0.10 \pm 0.01^{\mathrm{c}}$ & nd & $0.14 \pm 0.01^{\mathrm{c}}$ \\
\hline$\Sigma$ PUFA & $27.26 \pm 0.03^{\mathrm{a}}$ & $15.99 \pm 0.24^{\mathrm{b}}$ & $19.92 \pm 0.34^{\mathrm{c}}$ & $10.23 \pm 0.05^{\mathrm{d}}$ & $10.99 \pm 0.54^{\mathrm{d}}$ & $13.21 \pm 0.67^{\mathrm{e}}$ \\
\hline$\Sigma \mathrm{TFA}^{*}$ & $21.53 \pm 0.01^{\mathrm{a}, \mathrm{b}}$ & $34.78 \pm 0.81^{\mathrm{c}}$ & $17.17 \pm 0.62^{\mathrm{a}}$ & $25.59 \pm 0.27^{b}$ & $24.28 \pm 0.77^{\mathrm{b}}$ & $25.29 \pm 2.08^{\mathrm{b}}$ \\
\hline$\omega 3$ HUFA & $5.86 \pm 0.03^{\mathrm{a}, \mathrm{d}}$ & $9.52 \pm 0.12^{\mathrm{b}}$ & $5.18 \pm 0.05^{\mathrm{a}}$ & $6.77 \pm 0.02^{\mathrm{c}, \mathrm{d}}$ & $4.08 \pm 0.18^{\mathrm{e}}$ & $6.78 \pm 0.33^{\mathrm{c}}$ \\
\hline$\Sigma \omega 3$ & $7.80 \pm 0.03^{\mathrm{a}}$ & $10.35 \pm 0.14^{\mathrm{b}}$ & $7.08 \pm 0.14^{\mathrm{a}}$ & $7.04 \pm 0.01^{\mathrm{a}}$ & $4.41 \pm 0.20^{\mathrm{c}}$ & $7.14 \pm 0.34^{\mathrm{a}}$ \\
\hline$\Sigma \omega 6$ & $16.47 \pm 0.07^{\mathrm{a}}$ & $4.44 \pm 0.07^{\mathrm{b}}$ & $10.61 \pm 0.12^{\mathrm{c}}$ & $2.66 \pm 0.02^{\mathrm{d}}$ & $5.03 \pm 0.25^{\mathrm{b}}$ & $4.88 \pm 0.24^{\mathrm{b}}$ \\
\hline$\Sigma \omega 3 / \Sigma \omega 6$ & $0.47 \pm 0.00^{\mathrm{a}}$ & $2.33 \pm 0.01^{\mathrm{b}}$ & $0.67 \pm 0.01^{\mathrm{c}}$ & $2.64 \pm 0.02^{\mathrm{d}}$ & $0.88 \pm 0.00^{\mathrm{e}}$ & $1.46 \pm 0.00^{\mathrm{f}}$ \\
\hline EPA/AA & $0.50 \pm 0.00^{\mathrm{a}}$ & $2.55 \pm 0.01^{\mathrm{b}}$ & $0.61 \pm 0.00^{c}$ & $2.55 \pm 0.03^{\mathrm{b}}$ & $0.92 \pm 0.00^{\mathrm{d}}$ & $1.51 \pm 0.00^{\mathrm{e}}$ \\
\hline $\mathrm{H} / \mathrm{H}$ & $1.77 \pm 0.00^{\mathrm{a}}$ & $0.85 \pm 0.01^{\mathrm{b}}$ & $0.94 \pm 0.01^{\mathrm{c}}$ & $0.65 \pm 0.00^{\mathrm{d}}$ & $0.69 \pm 0.00^{\mathrm{e}}$ & $0.81 \pm 0.01^{\mathrm{f}}$ \\
\hline
\end{tabular}

The amount of TFA is expressed in $\mathrm{mg} / \mathrm{g}$ of dry weight basis

Data presented as mean \pm standard deviation $(n=5)$

Limit of detection for all fatty acids: $0.001 \%$; different letters in the same line have significant differences $(p<0.05)$

$n d$ not detected, $F A$ fatty acids, $S F A$ saturated fatty acids, $M U F A$ monounsaturated fatty acids, $P U F A$ polyunsaturated fatty acids, $A A$ arachidonic acid, EPA eicosapentaenoic acid, $\omega 3$ HUFA $\Sigma$ of $\omega 3$ highly unsaturated fatty acids $(20: 3 \omega 3,20: 4 \omega 3,20: 5 \omega 3,22: 3 \omega 3,22: 4 \omega 3,22: 5 \omega 3,22: 6 \omega 3)$, EPA/AA eicosapentaenoic acid/arachidonic acid, $\omega 3 / \omega 6 \Sigma$ of the fatty acids $\omega 3 / \Sigma$ of the fatty acids $\omega 6, H / H$ fatty acids hypocholesterolaemic/ hypercholesterolaemic ratios

*TFA: total fatty acids in $\mathrm{g}$ per $100 \mathrm{~g}$ of dry weight basis

${ }^{1}$ 4,8,12-trimethyltridecanoic acid

TFAs detected, which is similar to that observed for other Patella species described in the literature ( $P$. depressa, 26.78-33.83\%; P. ulyssiponensis, 22.12-27.13\%; P. vulgate, 28.35-32.92\%; P. rustica, 30.68-32.23\%; Patella peroni, 25.5\%) [14, 15]. However, Ezgeta-Balić, Najdek [17] reported lower levels of MUFAs in other marine molluscs, namely in oyster (Ostrea edulis, 6.78-20.05\%), mussels (Mytilus galloprovincialis, 7.70-16.46\%; Modiolus barbatus, 6.26-23.26\%) and ark shell (Arca noae, 6.71-22.60\%). In this class of FAs, oleic acid (OA, 18:1 $\omega 9)$ was the major FA found in both limpets collected at the several littoral zones studied, with the highest amounts verified in $P$. cande $i$ collected in Selvagens (28.25\% of TFA). The limpets under study presented much 
Table 4 Fatty acid composition of the edible mollusc P. aspera at several collection sites, expressed as \% of the total FA detected. The amount of TFA is expressed in $\mathrm{mg} / \mathrm{g}$ of dry weight basis

\begin{tabular}{|c|c|c|c|c|c|c|c|}
\hline $\begin{array}{l}\text { Fatty acid (\% of } \\
\text { TFA) }\end{array}$ & Selvagens & Garajau & $\begin{array}{l}\text { Ponta de São } \\
\text { Lourenço }\end{array}$ & Lido & Desertas & Rocha do Navio & Porto Moniz \\
\hline $13: 0^{1}$ & $2.36 \pm 0.07^{\mathrm{a}}$ & $3.18 \pm 0.14^{b, c}$ & $2.52 \pm 0.00^{\mathrm{a}, \mathrm{b}}$ & $1.37 \pm 0.04^{\mathrm{d}}$ & $4.00 \pm 0.31^{\mathrm{e}}$ & $3.51 \pm 0.36^{\mathrm{c}, \mathrm{e}}$ & $2.84 \pm 0.29^{\mathrm{a}, \mathrm{b}, \mathrm{c}}$ \\
\hline 14:0 & $4.54 \pm 0.09^{\mathrm{a}}$ & $7.61 \pm 0.36^{\mathrm{b}}$ & $7.02 \pm 0.05^{\mathrm{b}, \mathrm{c}}$ & $6.64 \pm 0.23^{\mathrm{b}, \mathrm{c}}$ & $5.42 \pm 0.47^{\mathrm{a}, \mathrm{c}}$ & $8.13 \pm 0.54^{\mathrm{b}}$ & $8.02 \pm 0.22^{\mathrm{b}}$ \\
\hline $15: 0$ & $1.40 \pm 0.03^{\mathrm{a}}$ & $1.50 \pm 0.06^{\mathrm{a}}$ & $1.46 \pm 0.00^{\mathrm{a}}$ & $0.97 \pm 0.01^{\mathrm{b}}$ & $1.14 \pm 0.08^{\mathrm{b}}$ & $1.51 \pm 0.08^{\mathrm{a}}$ & $1.77 \pm 0.11^{\mathrm{c}}$ \\
\hline $16: 0$ & $34.92 \pm 0.11^{\mathrm{a}}$ & $34.12 \pm 0.47^{\mathrm{a}}$ & $32.49 \pm 0.02^{\mathrm{a}}$ & $41.36 \pm 1.12^{\mathrm{b}}$ & $34.13 \pm 1.47^{\mathrm{a}}$ & $33.37 \pm 1.18^{\mathrm{a}}$ & $34.34 \pm 0.10^{\mathrm{a}}$ \\
\hline $17: 0$ & $1.25 \pm 0.01^{\mathrm{a}}$ & $0.89 \pm 0.01^{\mathrm{b}}$ & $0.58 \pm 0.01^{\mathrm{c}}$ & $0.64 \pm 0.01^{\mathrm{d}}$ & $0.61 \pm 0.00^{\mathrm{c}, \mathrm{d}}$ & $0.84 \pm 0.02^{\mathrm{e}}$ & $1.05 \pm 0.00^{\mathrm{f}}$ \\
\hline 18:0 & $10.09 \pm 0.07^{\mathrm{a}}$ & $9.53 \pm 0.38^{\mathrm{a}, \mathrm{b}}$ & $7.20 \pm 0.04^{\mathrm{c}, \mathrm{d}}$ & $6.42 \pm 0.01^{\mathrm{d}}$ & $7.52 \pm 0.03^{\mathrm{c}, \mathrm{d}, \mathrm{e}}$ & $8.30 \pm 0.66^{\mathrm{b}, \mathrm{c}, \mathrm{e}}$ & $9.07 \pm 0.08^{\mathrm{a}, \mathrm{b}, \mathrm{e}}$ \\
\hline 20:0 & $0.35 \pm 0.01^{\mathrm{a}}$ & $0.09 \pm 0.00^{\mathrm{b}}$ & $0.53 \pm 0.04^{c}$ & $0.54 \pm 0.01^{\mathrm{c}}$ & $0.22 \pm 0.00^{\mathrm{d}}$ & $0.19 \pm 0.00^{\mathrm{d}}$ & $0.18 \pm 0.01^{\mathrm{d}}$ \\
\hline 22:0 & $0.03 \pm 0.00^{\mathrm{a}}$ & $0.09 \pm 0.00^{\mathrm{b}}$ & $0.07 \pm 0.00^{\mathrm{b}}$ & $0.12 \pm 0.00^{c}$ & $0.28 \pm 0.00^{\mathrm{d}}$ & $0.19 \pm 0.00^{\mathrm{e}}$ & $0.02 \pm 0.00^{\mathrm{a}}$ \\
\hline$\Sigma$ SFA & $54.94 \pm 0.25^{\mathrm{a}}$ & $57.01 \pm 0.64^{\mathrm{a}}$ & $51.88 \pm 0.03^{\mathrm{a}}$ & $58.06 \pm 1.38^{\mathrm{a}}$ & $53.32 \pm 2.37^{\mathrm{a}}$ & $56.05 \pm 1.47^{\mathrm{a}}$ & $57.28 \pm 0.44^{\mathrm{a}}$ \\
\hline $16: 1 \omega 7$ & $1.80 \pm 0.10^{\mathrm{a}}$ & $3.59 \pm 0.10^{\mathrm{b}, \mathrm{c}}$ & $1.54 \pm 0.03^{\mathrm{a}}$ & $3.86 \pm 0.10^{\mathrm{c}}$ & $3.17 \pm 0.17^{\mathrm{b}}$ & $6.12 \pm 0.18^{\mathrm{d}}$ & $3.52 \pm 0.03^{\mathrm{b}, \mathrm{c}}$ \\
\hline $18: 1 \omega 9$ & $17.07 \pm 0.10^{\mathrm{a}}$ & $18.36 \pm 0.03^{\mathrm{b}}$ & $21.92 \pm 0.01^{\mathrm{c}}$ & $24.55 \pm 0.34 d$ & $19.22 \pm 0.43^{\mathrm{b}}$ & $18.60 \pm 0.11^{\mathrm{b}}$ & $16.81 \pm 0.18^{\mathrm{a}}$ \\
\hline 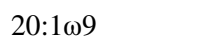 & $3.71 \pm 0.01^{\mathrm{a}}$ & $5.24 \pm 0.23^{\mathrm{abc}}$ & $6.00 \pm 0.16^{\mathrm{bc}}$ & $6.61 \pm 0.61^{\mathrm{c}}$ & $4.83 \pm 0.63^{\mathrm{abc}}$ & $5.94 \pm 0.52^{\mathrm{abc}}$ & $3.96 \pm 0.03^{\mathrm{ab}}$ \\
\hline$\Sigma$ MUFA & $22.58 \pm 0.02^{\mathrm{a}}$ & $27.19 \pm 0.10^{\mathrm{b}}$ & $29.46 \pm 0.13^{b c}$ & $35.02 \pm 0.85^{\mathrm{d}}$ & $27.21 \pm 0.89^{b}$ & $30.66 \pm 0.45^{\mathrm{c}}$ & $24.29 \pm 0.13^{\mathrm{a}}$ \\
\hline $18: 2 \omega 6$ & $0.46 \pm 0.03^{\mathrm{a}}$ & $0.52 \pm 0.01^{\mathrm{a}, \mathrm{b}}$ & $1.02 \pm 0.00^{\mathrm{c}}$ & $0.05 \pm 0.00^{\mathrm{d}}$ & $0.81 \pm 0.03^{\mathrm{e}}$ & $0.64 \pm 0.05^{\mathrm{b}}$ & $0.28 \pm 0.02^{f}$ \\
\hline $18: 2 \omega 3$ & nd & $0.27 \pm 0.00^{\mathrm{a}}$ & nd & $0.17 \pm 0.01^{\mathrm{b}}$ & nd & $0.21 \pm 0.03^{\mathrm{b}}$ & $0.08 \pm 0.00^{c}$ \\
\hline $18: 3 \omega 3$ & $0.65 \pm 0.03^{\mathrm{a}}$ & $0.30 \pm 0.01^{b}$ & $1.20 \pm 0.01^{\mathrm{c}}$ & nd & $1.56 \pm 0.06^{\mathrm{d}}$ & $0.77 \pm 0.09^{\mathrm{a}}$ & $0.05 \pm 0.00^{\mathrm{e}}$ \\
\hline $18: 4 \omega 3$ & $0.12 \pm 0.01^{\mathrm{a}}$ & $0.04 \pm 0.00^{\mathrm{b}}$ & $0.09 \pm 0.00^{\mathrm{c}}$ & nd & $0.13 \pm 0.00^{\mathrm{a}}$ & $0.08 \pm 0.00^{\mathrm{c}}$ & $0.05 \pm 0.00^{\mathrm{b}}$ \\
\hline $20: 2 \omega 9$ & $1.04 \pm 0.00^{\mathrm{a}, \mathrm{b}}$ & $1.11 \pm 0.07^{\mathrm{b}}$ & $2.12 \pm 0.02^{\mathrm{c}}$ & $0.70 \pm 0.08^{\mathrm{a}}$ & $1.91 \pm 0.25^{\mathrm{c}}$ & $1.17 \pm 0.10^{\mathrm{b}}$ & $0.83 \pm 0.02^{\mathrm{a}, \mathrm{b}}$ \\
\hline $20: 3 \omega 6$ & $0.06 \pm 0.00^{\mathrm{a}}$ & $0.13 \pm 0.02^{\mathrm{b}, \mathrm{c}}$ & $0.18 \pm 0.01^{\mathrm{c}}$ & nd & $0.08 \pm 0.00^{\mathrm{a}, \mathrm{b}}$ & $0.10 \pm 0.01^{\mathrm{a}, \mathrm{b}}$ & $0.09 \pm 0.01^{\mathrm{a}, \mathrm{b}}$ \\
\hline $20: 4 \omega 6$ - AA & $7.17 \pm 0.05^{\mathrm{a}}$ & $4.36 \pm 0.17^{\mathrm{b}}$ & $7.34 \pm 0.05^{\mathrm{a}}$ & $1.67 \pm 0.15^{\mathrm{c}}$ & $8.73 \pm 0.69^{\mathrm{a}}$ & $4.09 \pm 0.41^{\mathrm{b}}$ & $4.70 \pm 0.06^{\mathrm{b}}$ \\
\hline $20: 4 \omega 3$ & $0.12 \pm 0.02^{\mathrm{a}, \mathrm{b}}$ & $0.07 \pm 0.00^{\mathrm{a}, \mathrm{c}}$ & $0.17 \pm 0.01^{b}$ & nd & $0.05 \pm 0.00^{\mathrm{c}, \mathrm{d}}$ & $0.04 \pm 0.00^{\mathrm{c}, \mathrm{d}}$ & $0.05 \pm 0.01^{\mathrm{c}, \mathrm{d}}$ \\
\hline $20: 5 \omega 3$-EPA & $12.59 \pm 0.28^{\mathrm{a}}$ & $8.75 \pm 0.25^{\mathrm{b}}$ & $6.29 \pm 0.03^{\mathrm{c}}$ & $4.24 \pm 0.28^{\mathrm{d}}$ & $6.19 \pm 0.43^{c}$ & $5.93 \pm 0.35^{\mathrm{c}}$ & $12.12 \pm 0.32^{\mathrm{a}}$ \\
\hline $22: 4 \omega 6$ & $0.10 \pm 0.00^{\mathrm{a}}$ & $0.04 \pm 0.00^{\mathrm{b}}$ & $0.15 \pm 0.00^{\mathrm{c}}$ & nd & $0.02 \pm 0.00^{\mathrm{d}}$ & nd & nd \\
\hline $22: 5 \omega 3$ & $0.17 \pm 0.01^{\mathrm{a}}$ & $0.20 \pm 0.02^{\mathrm{a}}$ & $0.11 \pm 0.01^{\mathrm{b}}$ & $0.08 \pm 0.00^{\mathrm{b}}$ & nd & $0.08 \pm 0.00^{\mathrm{b}}$ & $0.17 \pm 0.01^{\mathrm{a}}$ \\
\hline $22: 6 \omega 3-\mathrm{DHA}$ & nd & $0.02 \pm 0.00^{\mathrm{a}}$ & nd & nd & nd & $0.19 \pm 0.02^{\mathrm{b}}$ & nd \\
\hline$\Sigma$ PUFA & $22.48 \pm 0.24^{\mathrm{a}}$ & $15.81 \pm 0.54^{\mathrm{b}, \mathrm{c}}$ & $18.66 \pm 0.16^{\mathrm{a}, \mathrm{b}}$ & $6.92 \pm 0.53^{\mathrm{d}}$ & $19.47 \pm 1.47^{\mathrm{a}, \mathrm{b}}$ & $13.30 \pm 1.01^{\mathrm{c}}$ & $18.43 \pm 0.31^{\mathrm{a}, \mathrm{b}}$ \\
\hline$\Sigma \mathrm{TFA}^{*}$ & $18.01 \pm 0.65^{\mathrm{a}}$ & $28.66 \pm 1.20^{\mathrm{b}, \mathrm{c}}$ & $36.38 \pm 0.37^{\mathrm{d}}$ & $32.67 \pm 2.51^{\mathrm{c}, \mathrm{d}}$ & $19.64 \pm 2.14^{\mathrm{a}}$ & $27.40 \pm 1.75^{\mathrm{b}, \mathrm{c}}$ & $25.93 \pm 0.47^{b}$ \\
\hline$\omega 3$ HUFA & $12.88 \pm 0.26^{\mathrm{a}}$ & $9.04 \pm 0.27^{\mathrm{b}}$ & $6.57 \pm 0.05^{\mathrm{c}}$ & $4.32 \pm 0.28^{\mathrm{d}}$ & $6.23 \pm 0.43^{c}$ & $6.23 \pm 0.34^{c}$ & $12.35 \pm 0.30^{\mathrm{a}}$ \\
\hline$\Sigma \omega 3$ & $13.65 \pm 0.22^{\mathrm{a}}$ & $9.65 \pm 0.27^{b}$ & $7.86 \pm 0.07^{\mathrm{b}, \mathrm{c}}$ & $4.50 \pm 0.30^{\mathrm{d}}$ & $7.92 \pm 0.49^{\mathrm{b}, \mathrm{c}}$ & $7.29 \pm 0.46^{c}$ & $12.52 \pm 0.30^{\mathrm{a}}$ \\
\hline$\Sigma \omega 6$ & $7.78 \pm 0.02^{\mathrm{a}}$ & $5.05 \pm 0.20^{\mathrm{b}}$ & $8.68 \pm 0.07^{\mathrm{a}}$ & $1.72 \pm 0.16^{\mathrm{c}}$ & $9.65 \pm 0.73^{\mathrm{a}}$ & $4.83 \pm 0.46^{\mathrm{b}}$ & $5.08 \pm 0.03^{\mathrm{b}}$ \\
\hline$\Sigma \omega 3 / \Sigma \omega 6$ & $1.75 \pm 0.02^{\mathrm{a}}$ & $1.91 \pm 0.02^{\mathrm{a}}$ & $0.91 \pm 0.00^{\mathrm{b}}$ & $2.61 \pm 0.06^{\mathrm{c}}$ & $0.82 \pm 0.01^{\mathrm{b}}$ & $1.51 \pm 0.05^{\mathrm{d}}$ & $2.47 \pm 0.05^{\mathrm{c}}$ \\
\hline EPA/AA & $1.76 \pm 0.03^{\mathrm{a}}$ & $2.01 \pm 0.02^{\mathrm{b}}$ & $0.86 \pm 0.00^{\mathrm{c}}$ & $2.54 \pm 0.07^{\mathrm{d}}$ & $0.71 \pm 0.01^{\mathrm{c}}$ & $1.45 \pm 0.06^{\mathrm{e}}$ & $2.58 \pm 0.04^{\mathrm{d}}$ \\
\hline DHA/EPA & - & - & - & - & - & $0.03 \pm 0.01$ & - \\
\hline $\mathrm{H} / \mathrm{H}$ & $0.97 \pm 0.01^{\mathrm{a}}$ & $0.78 \pm 0.01^{\mathrm{b}, \mathrm{c}}$ & $0.96 \pm 0.00^{\mathrm{a}}$ & $0.66 \pm 0.05^{\mathrm{d}}$ & $0.92 \pm 0.01^{\mathrm{a}}$ & $0.73 \pm 0.01^{b}$ & $0.81 \pm 0.01^{\mathrm{c}}$ \\
\hline
\end{tabular}

Data presented as mean \pm standard deviation $(n=4)$

Limit of detection for all fatty acids: $0.001 \%$; different letters in the same line have significant differences $(p<0.05)$

$n d$ not detected, FA fatty acids, SFA saturated fatty acids, MUFA monounsaturated fatty acids, PUFA polyunsaturated fatty acids, AA arachidonic acid, EPA eicosapentaenoic acid, DHA docosahexaenoic acid, $\omega 3$ HUFA $\Sigma$ of $\omega 3$ highly unsaturated fatty acids $(20: 3 \omega 3,20: 4 \omega 3,20: 5 \omega 3$, 22:3 $\omega 3,22: 4 \omega 3,22: 5 \omega 3,22: 6 \omega 3), E P A / A A$ eicosapentaenoic acid/arachidonic acid, DHA/EPA docosahexaenoic acid/eicosapentaenoic acid, $\omega 3 /$ $\omega 6 \Sigma$ of the fatty acids $\omega 3 / \Sigma$ of the fatty acids $\omega 6, H / H$ fatty acids hypocholesterolaemic/hypercholesterolaemic ratios

*TFA: total fatty acids in $\mathrm{g}$ per $100 \mathrm{~g}$ of dry weight basis

1 4,8,12-trimethyltridecanoic acid

larger amounts of OA (about two or three times higher) than other limpets described in literature, namely P. peroni collected Southeast of Melbourne (8.3\%) [15]; P. depressa (5.04-8.29\%), P. ulyssiponensis (5.04-6.91\%), P. vulgata $(6.97-11.60 \%)$ and P. rustica $(4.22-7.01 \%)$ collected at different shores of Portuguese coast [14]; as well as, Lepetodrilus spp. collected in hydrothermal vent field of the East Pacific (10.3\%) [35]. Likewise, Ezgeta-Balić, Najdek [17] reported much lower amounts of OA in other commercially important molluscs species, such as European 
flat oyster (Ostrea edulis, 2.12-6.34\%), black mussel (Mytilus galloprovincialis, 1.22-16.95\%), bearded horse mussel (Modiolus barbatus, 1.67-3.28\%) and Noah's ark shell (Arca noae, 1.95-5.38\%).

The ingestion of OA has been related to the level of lowdensity proteins in blood, the prevention of arteriosclerosis and the stimulation of bile secretion (necessary for digestion and absorption of fats) [5, 38]. Therefore, the high levels of OA, verified in the samples analysed, suggest that the introduction of $P$. aspera and $P$. candei in human diet can bring health benefits.

The other MUFAs characteristic of Patella species were

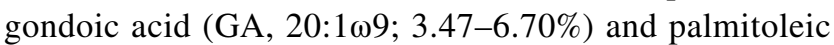

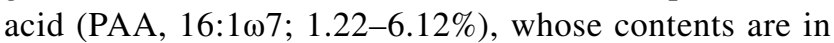
agreement with limpet $P$. peroni described by Johns, Nichols [15] and to different limpet species found by Brazão, Morais [14] in the Portuguese coast.

\section{Polyunsaturated fatty acids}

The two limpets under study presented remarkable differences across sites in their PUFAs contents, ranging among 6.92-22.48\% and 10.23-27.26\% of TFA in P. aspera and $P$. candei, respectively. Eicosapentaenoic acid (EPA, 20:5 13 )

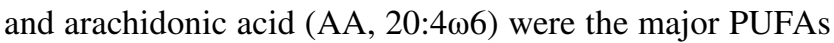
found in samples. The highest levels of EPA ( $\omega 3$ LC-PUFAs) were found in P. aspera collected at Selvagens (12.59\%), while $P$. candei exhibited highest contents of AA (11.38\%, $\omega 6$ LC-PUFAs) at the same site. The other important $\omega 3$ LCPUFA identified, only in P. aspera, was docosahexaenoic

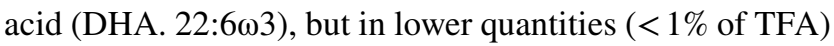
compared to AA and EPA contents. Brazão, Morais [14] reported similar levels of LC-PUFAs, EPA (6.35-19.74\%), AA (5.20-14.21\%) and DHA (0.11-1.03\%), in other limpets species collected in Portuguese coast, namely, P. depressa, $P$. ulyssiponensis, $P$. vulgata and $P$. rustica. Although, in limpet P. peroni from littoral zone of Australia, Johns, Nichols [15] did not detect AA and DHA, high amounts of EPA were found (24.9\%). Still, Zhukova [34] in other molluscs, namely nudibranchs from South China Sea, reported very low levels of EPA (0.6\%), slightly lower values of AA (6.5-8.9\%) and similar amounts of DHA (1\%). In addition, Ezgeta-Balić, Najdek [17] found in commercial important bivalves (oyster, mussels and ark shell) from eastern Adriatic Sea similar levels of EPA (2.72-28.25\%) and AA (0.30-8.82\%), while the levels of DHA were highest $(2.98-41.37 \%)$ than those reported in the present study.

The introduction of PUFAs in human nutrition through the consumption of molluscs, namely through limpets, may have health benefits, since the consumption of PUFAs is indicated for the reduction of total cholesterol in blood and plasma LDL cholesterol levels [31]. Besides, the highest ingestion of $\omega 3$ LC-PUFAs (EPA and DHA) promotes reduction of plasma triglyceride levels by decreasing hepatic synthesis of VLDL cholesterol and may have other cardiovascular effects, such as reduced blood viscosity, increased endothelium relaxation and antiarrhythmic effects [31]. Moreover, these PUFAs alleviate symptoms of relation in rheumatoid arthritis, decreasing of mild hypertension, lowering the incidence of diabetes and prevent some cancers [9]. However, the highest ingestion of $\omega 6$ LC-PUFAs (AA) can suppress and stimulate immune response [31].

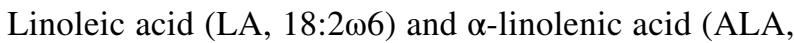
$18: 3 \omega 3)$ are two other PUFAs that were detected in the fatty acid profile of both $P$. aspera and $P$. candei. These two fatty acids are considered essential for human diet since their intake through PUFA-rich sources is mandatory. The greatest amounts of essential fatty acids in $P$. cande $i$ were found in Selvagens (6.71\%) and in P. aspera collected at Desertas $(2.37 \%)$.

Western diets are characterized by lower $\omega 3$ fatty acids intake and higher $\omega 6$ FA $(1: 20)[39,40]$. A balanced ratio of $\Sigma \omega 3 / \Sigma \omega 6$ FA (around 1:1) is known to be important for health and in the prevention and management of inflammatory, autoimmune and neurodegenerative diseases [39, 40]. This balance can best be accomplished by the consumption of products with high levels of $\omega 3$ PUFAs and small amounts of $\omega 6$ PUFAs $[39,40]$. In the present study, all samples of limpets analysed contained a good $\Sigma \omega 3 / \Sigma \omega 6$ (Tables 3, 4), with emphasis on both $P$. candei and $P$. aspera collected in Lido that comprised the highest ratio of 2.64 and 2.61, respectively. This suggests that these marine molluscs possess a good nutritional ratio for dietary intake.

The $\Sigma$ hypocholesterolaemic/ $\Sigma$ hypercholesterolaemic fatty acids ratio $(\mathrm{H} / \mathrm{H})$ is associated to cholesterol metabolism and high values of this ratio is considered a positive aspect for human health [23]. In this study, the marine molluscs studied exhibited high values of $\mathrm{H} / \mathrm{H}$ index, greater than 0.65 (Tables 3, 4), with the highest value found for $P$. candei in Selvagens (1.77).

\section{Principal component analysis}

The quality of lipids is known to vary with environmental factors such as distribution, temperature and food availability. Therefore, the principal component analysis (PCA) was performed to study the biochemical changes triggered by geographical distribution of the limpet species. Figure $2 \mathrm{a}$ represents the distribution of the loadings in a two-component model for $P$. candei. The first component (PC1) accounted for $49 \%$, whereas the second component (PC2) accounted for $29 \%$ of the total variance, which together explained $78 \%$ of the total variance. The loadings are widely distributed in the factorial plan, and it is possible to detect some groups of variables in different zones of the plot. The palmitoleic acid (PAA) and MA along with SFA 

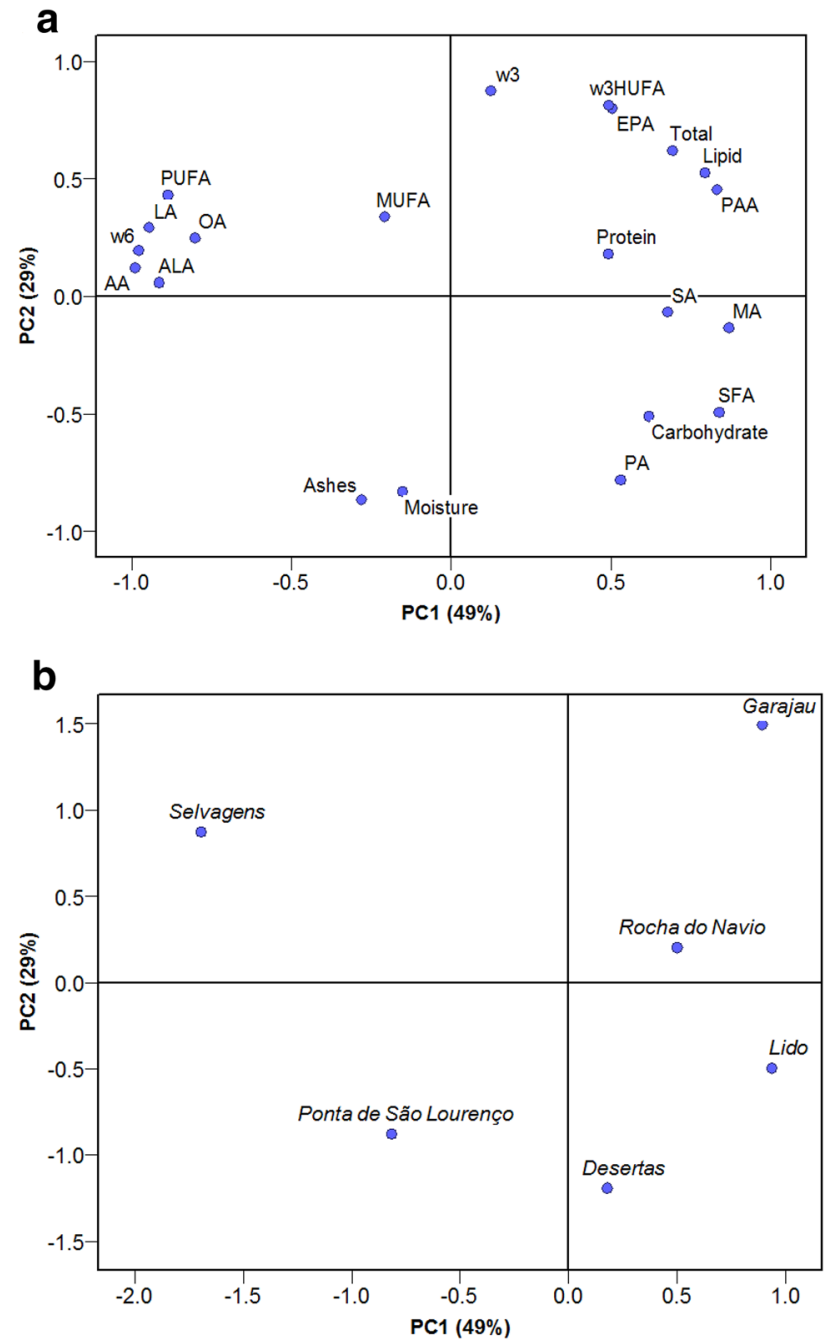

Fig. 2 Principal component analysis (PCA) of the most important fatty acid composition of $P$. cande $i$ samples in different sites, including the ratio

are positively correlated to principal component 1 , whereas $\omega 6$, OA, LA, ALA, AA and PUFAs are strongly associated to negative values of factor 1 . The $\omega 3, \omega 3$ HUFA and EPA, located on the upper-right quadrant of the factorial plan, are strongly correlated to the positive values of principal component 2.

With respect to $P$. aspera, the first component (PC1) accounted for $42 \%$, whereas the second component (PC2) accounted for $26 \%$ of the total variance, which together explained $68 \%$ of the total variance (Fig. 3a). The cluster $\omega 3, \omega 3$ LC-PUFA, EPA and SA are positively associated to factor 1 , as well as, the levels of PUFA, despite its location on the lower-right quadrant of the factorial plan. Moreover, the variables $\omega 6$, LA, ALA and AA are negatively associated to factor 2, while the levels of SFA are strongly correlated to positive values to the same factor.
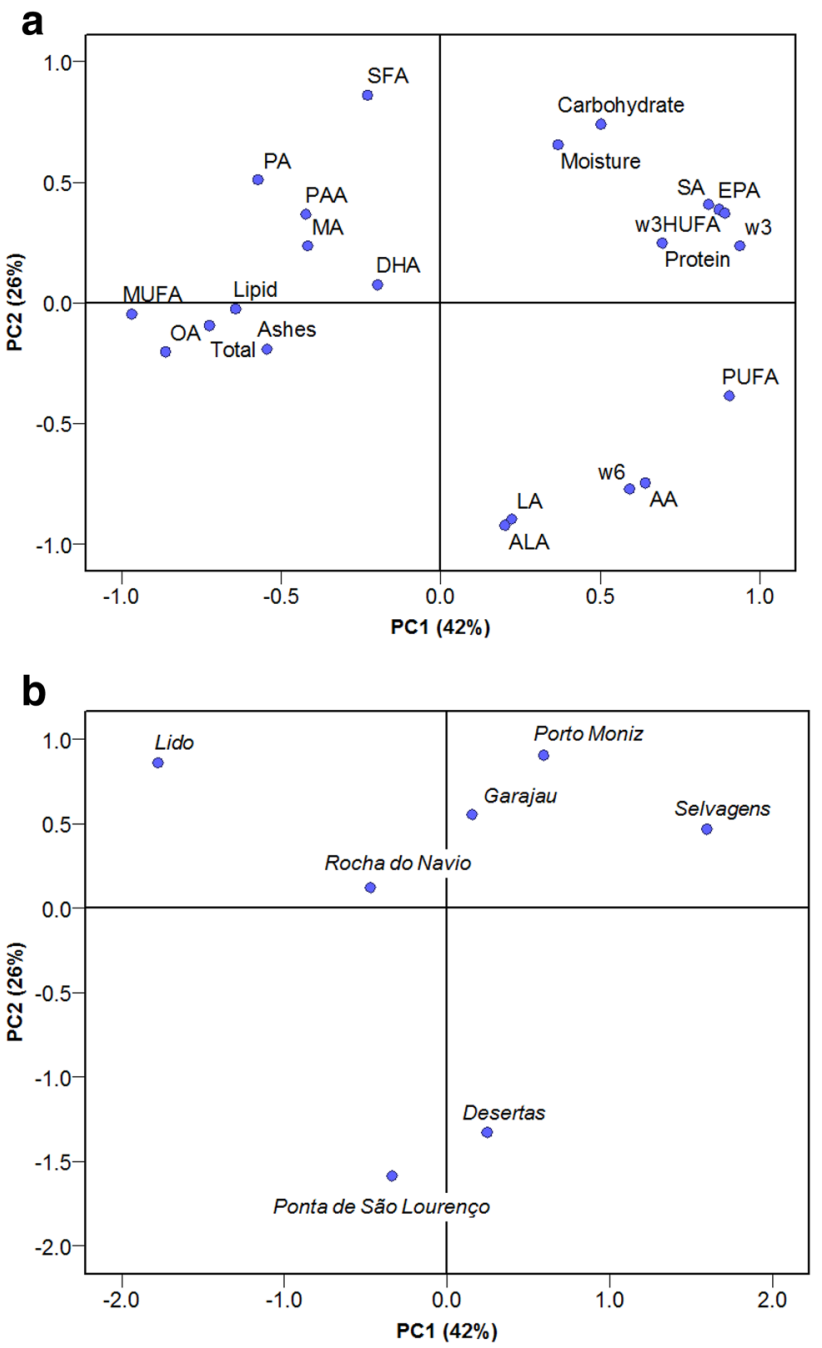

Fig. 3 Principal component analysis (PCA) of the most important fatty acid composition of $P$. aspera samples in different sites, including the ratio

Figures $2 b$ and $3 b$ show the projection of the factor scores on the two principal component models for the two patella species collected at different sites. Comparing the loadings with their corresponding score plots, it is clear that the distribution of the limpets studied had influence on their biochemical composition, which, in turn, is connected with their dietary value. This might indicate which environmental factors are needed to fulfil these marine invertebrates' requirements to enhance their biochemical composition to the final consumer.

In P. candei (Fig. 2b), higher amounts of PA and SFA cause the scores of Lido and Desertas to be located on the lower-right quadrant of the factorial plan. While high contents of $\omega 3$ fatty acid, namely EPA, led the separation of Garajau to the upper-right quadrant of the scores plot. Furthermore, the positioning of Selvagens in the upper-left quadrant, which is strongly associated to negative values of 
$\mathrm{PC} 1$, confirm that this limpet specie at this site had a richer diet in $\omega 6$ and $\omega 9$ fatty acids, namely LA, AA and OA.

In P. aspera (Fig. 3b), Lido and Rocha do Navio are located in the upper-left quadrant, which is positively associated to PC1 and negatively associated to PC2 values, denoting highest levels of PA. There are some macroalgal taxa that have been reported to have a frequent abundance in the intertidal zone of both North and South of Madeira Island (e.g. Colpomenia sinuosa and Dasycladus vermicularis) [41]. This fact might explain the similar strong correlations to PA in limpets from Lido (South) and Rocha do Navio (North). Moreover, Rocha do Navio is strongly negatively related to PC2 values, confirming highest amounts of DHA. The location of Desertas in the lower-right quadrant (strongly associated to negative values of PC1) might reflect a richer diet in $\omega 6$ fatty acid, in particular LA and AA. The strong correlation of Selvagens with the positive values of PC1 confirms highest levels of $\omega 3$ PUFA, namely in EPA ( $\omega 3$ LC-PUFA), in limpet species collected at this site.

The quality and quantity of algal lipids is very important in marine molluscs diet, because they cannot efficiently synthesize PUFA by de novo synthesis, acquiring the essential fatty acids (AA, EPA and DHA) through diet [13]. In this study, the highest proportions of PA and the lowest levels of essential fatty acids verified in both Patella species collected in Lido suggest that the diet composition was poor in algae, this might be a consequence of the excessive anthropogenic activity that occurs in this location [14, 41]. On the other hand, the highest proportions of $\omega 6$ LC-PUFAs, particularly AA, in $P$. candei from Selvagens and $P$. aspera from Desertas may reflect a rich diet in brown algae and diatoms (Bacillariophyceae), which are known to be rich sources of AA and EPA, explaining the highest amounts of AA and the presence of good contents in EPA [14]. Regarding the highest proportions of $\omega 3$ LC-PUFAs, namely EPA, in Garajau (P. can$d e i)$ and Selvagens (P. aspera), it is concluded that the diet composition of limpet in this sites may be mostly constituted by red algae (Rhodophyta) and encrusting algae (rich in $\omega 3$ PUFAs, mainly EPA) [14]. Moreover, the presence of DHA proportions in P. aspera from Rocha do Navio, although in low quantities, may suggest that this site contains dinoflagellates (Dinophyceae), a rich source of DHA [14].

\section{Conclusions}

P. aspera and P. candei showed different proximate and fatty acid compositions. $P$. candei showed higher levels of moisture and ashes, while $P$. aspera comprised higher amounts of lipids, proteins and carbohydrates. With regard to the fatty acid composition $P$. cande $i$ had higher content of PUFAs,
OA and AA, while P. aspera presented higher levels of EPA. Through the principal component analysis it was possible to visualize the effect of the geographical distribution of limpets in their dietary value and fatty acid composition. This study demonstrated that $P$. aspera and $P$. cande $i$ are good sources of long chain PUFAs, highlighting their potential health benefits through dietary intake.

Acknowledgements This study was partially supported by the Oceanic Observatory of Madeira (M1420-01-0145-FEDER-000001-Observatório Oceânico da Madeira-OOM).

\section{Compliance with ethical standards}

Conflict of interest The authors declare that they have no conflict of interest.

Compliance with ethics requirements This article does not contain any studies with human or animal subjects.

\section{References}

1. Fishery Statistical Collections: Consumption of Fish and Fishery Products (2018) Food and Agriculture Organization of the United Nation, Rome. http://www.fao.org/fishery/statistics/global-consu mption/en. Accessed 23 Aug 2018

2. Weber LI, Hawkins SJ (2002) Evolution of the limpet Patella candei d'Orbigny (Mollusca, Patellidae) in Atlantic archipelagos human intervention and natural processes. Biol J Linnean Soc 77:341-353

3. Weber LI, Hawkins SJ (2005) Patella aspera and P. ulyssiponensis: genetic evidence of speciation in the North-east Atlantic. Mar Biol 147:153-162

4. Pereira DM, Valentao P, Teixeira N, Andrade PB (2013) Amino acids, fatty acids and sterols profile of some marine organisms from Portuguese waters. Food Chem 141:2412-2417

5. Reale A, Ziino M, Ottolenghi F, Pelusi P, Romeo V, Condurso C, Sanfilippo M (2006) Chemical composition and nutritional value of some marine species from the Egadi Islands. Chem Ecol 22:173-179

6. Sirot V, Oseredczuk M, Bemrah-Aouachria N, Volatier J-L, Leblanc J-C (2008) Lipid and fatty acid composition of fish and seafood consumed in France: CALIPSO study. J Food Compos Anal 21:8-16

7. Almeida C, Karadzic V, Vaz S (2015) The seafood market in Portugal: driving forces and consequences. Mar Policy 61:87-94

8. Fernandes T, Fernandes I, Andrade CAP, Cordeiro N (2016) Changes in fatty acid biosynthesis in marine microalgae as a response to medium nutrient availability. Algal Res 18:314-320

9. Prato E, Biandolino F (2012) Total lipid content and fatty acid composition of commercially important fish species from the Mediterranean, Mar Grande Sea. Food Chem 131:1233-1239

10. Nogueira N, Fernandes I, Fernandes T, Cordeiro N (2017) A comparative analysis of lipid content and fatty acid composition in muscle, liver and gonads of Seriola fasciata Bloch 1793 based on gender and maturation stage. J Food Compos Anal 59:68-73

11. Saito H, Aono H (2014) Characteristics of lipid and fatty acid of marine gastropod Turbo cornutus: high levels of arachidonic and n-3 docosapentaenoic acid. Food Chem 145:135-144

12. Tsape K, Sinanoglou VJ, Miniadis-Meimaroglou S (2010) Comparative analysis of the fatty acid and sterol profiles of widely 
consumed Mediterranean crustacean species. Food Chem 122:292-299

13. Lund EK (2013) Health benefits of seafood; is it just the fatty acids? Food Chem 140:413-420

14. Brazão S, Morais S, Boaventura D, Ré P, Narciso LS, Hawkins SJ (2003) Spatial and temporal variation of the fatty acid composition of Patella spp. (Gastropoda: Prosobranchia) soft bodies and gonads. Comp Biochem Physiol B Biochem Mol Biol 136:425-441

15. Johns RB, Nichols PD, Perr GJ (1980) Fatty acid components of nine species of molluscs of the littoral zone from Australian waters. Comp Biochem Physiol B Biochem Mol Biol 6511:207-214

16. Hermida M, Delgado J (2016) High trophic level and low diversity: Would Madeira benefit from fishing down? Mar Policy 73:130-137

17. Ezgeta-Balić D, Najdek M, Peharda M, Blažina M (2012) Seasonal fatty acid profile analysis to trace origin of food sources of four commercially important bivalves. Aquaculture 334-337:89-100

18. Kalogeropoulos N, Chiou A, Ioannou M, Karathanos VT, Hassapidou M, Andrikopoulos NK (2010) Nutritional evaluation and bioactive microconstituents (phytosterols, tocopherols, polyphenols, triterpenic acids) in cooked dry legumes usually consumed in the Mediterranean countries. Food Chem 121:682-690

19. Bligh EG, Dyer WJ (1959) A rapid method of total lipid extraction and purification. Can J Biochem Physiol 37:911-917

20. Fernandes T, Fernandes I, Andrade CA, Cordeiro N (2016) Marine microalgae growth and carbon partitioning as a function of nutrient availability. Bioresour Technol 214:541-547

21. Lepage G, Roy CC (1986) Direct transesterification of all classes of lipids in a one-step reaction. J Lipid Res 27:114-120

22. Cohen Z, Vonshak A, Richmond A (1988) Effect of environmental conditions on fatty acid composition of the red alga porphyridium correlation to growth rate. J Phycol 24:328-332

23. Fernandes CE, Vasconcelos MA, Ribeiro Mde A, Sarubbo LA, Andrade SA, Filho AB (2014) Nutritional and lipid profiles in marine fish species from Brazil. Food Chem 160:67-71

24. Sidwell VD, Bonnet JC, Zook EG (1973) Chemical and nutritive values of several fresh and canned finfish, crustaceans, and mollusks part I: proximate composition, calcium, and phosphorus. Mar Fish Rev 35:16-19

25. Ackman RG (1990) Seafood lipids and fatty acids. Food Rev Int 6:617-646

26. Pogoda B, Buck BH, Saborowski R, Hagen W (2013) Biochemical and elemental composition of the offshore-cultivated oysters Ostrea edulis and Crassostrea gigas. Aquaculture 400-401:53-60

27. Karakoltsidis PA, Zotos A, Constantinides SM (1995) Composition of the commercially important Mediterranean finfish, crustacean, and molluscs. J Food Compos Anal 8:258-273
28. Murray J, Burt JR (1983) The composition of fish. Ministry of Agriculture, Torry Research Station

29. Miletic I, Miric M, Lalic Z, Sobajic S (1991) Composition of lipids and proteins of several species of molluscs, marine and terrestrial, from the Adriatic Sea and Serbia. Food Chem 41:303-308

30. Linehan LG, O'Connor TP, Burnell G (1999) Seasonal variation in the chemical composition and fatty acid profile of Pacific oysters (Crassostrea gigas). Food Chem 64:211-214

31. Berto A, Silva AF, Visentainer JV, Matsushita M, Souza NE (2015) Proximate compositions, mineral contents and fatty acid compositions of native Amazonian fruits. Food Res Int 77:441-449

32. Ventrella V, Pirini M, Pagliarani A, Trombetti F, Manuzzi MP, Borgatti AR (2008) Effect of temporal and geographical factors on fatty acid composition of $M$. galloprovincialis from the Adriatic sea. Comp Biochem Physiol B Biochem Mol Biol 149:241-250

33. Piretti MV, Taioli F, Pagliuca G (1987) Investigation of the seasonal variations of sterol and fatty acid constituents in the bivalve molluscs Venus gallina and Scapharca inaequivalvis (Bruguiére). Comp Biochem Physiol B Biochem Mol Biol 4:1201-1208

34. Zhukova NV (2007) Lipid classes and fatty acid composition of the tropical nudibranch mollusks Chromodoris sp. and Phyllidia coelestis. Lipids 42:1169-1175

35. Phleger CF, Nelson MM, Groce AK, Cary SC, Coyne KJ, Nichols PD (2005) Lipid composition of deep-sea hydrothermal vent tubeworm Riftia pachyptila, crabs Munidopsis subsquamosa and Bythograea thermydron, mussels Bathymodiolus sp. and limpets Lepetodrilus spp. Comp Biochem Physiol B Biochem Mol Biol 141:196-210

36. Misra S, Choudhury A, Ghosh A (1986) Lipids and fatty acids of the gastropod mollusc Cerithidea obtusa. Food Chem 22:251-258

37. Williams CM (2000) Dietary fatty acids and human health. Ann Zootech 49:165-180

38. Santos LP, Morais DR, Souza NE, Cottica SM, Boroski M, Visentainer JV (2011) Phenolic compounds and fatty acids in different parts of Vitis labrusca and V. vinifera grapes. Food Res Int 44:1414-1418

39. Simopoulos AP (2016) An increase in the omega-6/omega-3 fatty acid ratio increases the risk for obesity. Nutrients 8(1-17): 128

40. Simopoulos AP (2010) The omega-6/omega-3 fatty acid ratio: health implications. OCL 17:267-275

41. Ferreira SJF (2013) Contributo para o estudo das Macroalgas do Intertidal da ilha da Madeira: Diversidade, Distribuição e Sazonalidade. Master Thesis, University of Madeira, Funchal

Publisher's Note Springer Nature remains neutral with regard to jurisdictional claims in published maps and institutional affiliations. 